応用論文

\title{
拡張現実型聴診訓練システムにおける カメラ内蔵型聴診器デバイスの開発
}

\author{
関口陽太 ${ }^{1)}$, 中俊哉 ${ }^{2)}$, 村竹虎和 ${ }^{3)}$, 三浦慶一郎 ${ }^{4)}$ \\ 川田奈緒子 ${ }^{5)}$, 吉村裕一郎 ${ }^{2)}$, 伊藤彰一 ${ }^{6,7)}$, 朝比奈真由美 ${ }^{6,7)}$, 田邊政裕 ${ }^{8)}$
}

\section{1.はじめに}

医学教育において臨床技術の習得は非常に重要 であり，現在の医学教育機関では客観的臨床能力
試験（Objective Structured Clinical Examination;

OSCE）を臨床実習に進む前に実施している ${ }^{1,2}$ 。 この試験はペーパーテストなどで評価し難い「基 本的な診察能力」と「患者とのコミュニケーショ

\section{Development of Camera built-in Stethoscope Device for AR-Based Auscultation Training Simulator}

\author{
Yota Sekiguchi, Toshiya Nakaguchi, Torakazu Muratake, Keiichiro Miura, Naoko Kawada, \\ Yuichiro Yoshimura, Shoichi Ito, Mayumi Asahina, Masahiro Tanabe
}

\begin{abstract}
:
Current auscultatory training is constructed by using simulated patients (SPs) and auscultatory training mannequins. Through this method can perform training with various biological sounds, it has several disadvantages: communication between patients and doctors is inconvenient in the training; lack of reality; movement and installation are difficult. We have proposed the system called EARS (Educational Augmented Reality auscultation System) which can reproduce cardiovascular and pulmonary sounds to SPs by using augmented reality technology. This system makes it possible to train medical interviews and auscultatory techniques to SPs. Conventional EARS has disadvantages that installation is complicated, limited to use of sitting position only, and malfunction may occur due to blocking of infrared light by occlusion. In this research, we produced stethoscope device integrating camera, infrared light source, synchronization circuit, wired voice communication circuit, OLED (Organic Light Emitting Diode) panel. We also propose a method to detect the position of stethoscope in any posture of SPs. That make the new system easier to install and reduces the restriction on the posture. By evaluating the operational stability and positional detection accuracy comparing with the conventional EARS system, it is confirmed that the proposed system has significantly improved performance.
\end{abstract}

Key words :

VR Surgery Simulator, Modeling of 3D Organ, Anomaly, Cystic Duct and Artery

1）千葉大学大学院融合理工学府基幹工学専攻, Graduate School of Science and Engineering, Chiba University

2) 千葉大学フロンティア医工学センター, Center for Frontier Medical Engineering, Chiba university

3）ケンツメディコ株式会社, KENZMEDICO Inc.

4) 千葉大学大学院医学研究院循環器内科学, Department of Cardiovascular Medicine, Chiba University Graduate School of Medicine

5) 千葉大学大学院医学研究院呼吸器内科学, Department of Respirology, Chiba University Graduate School of Medicine

6) 千葉大学大学院医学研究院医学教育研究室, Office of Medical Education, Chiba University Graduate School of Medicine

7）千葉大学医学部附属病院総合医療教育研修センター, Health Professional Development Center, Chiba University Hospital

8）千葉県立保健医療大学, Chiba Prefectural University of Health Sciences 
ン能力」といった臨床能力の習熟度を評価するこ とを目的としている。また，2020 年度からは卒業 時の能力を評価する臨床実習後 OSCE (Post-Clinical Clerkship OSCE; Post-CC_OSCE）の全国的な実施 が予定されており，実際の臨床研修に必要とされ る高度な臨床技術の習得が求められている ${ }^{3)}$ 。

基本的な臨床手技の 1 つである聴診は, 多くの 生体情報を非侵襲的かつ迅速に取得できる ${ }^{4)} 。 し$ かし, 聴診器を通して聴こえる生体音から異常を 判別し, 実際の臨床現場で診察に用いるには十分 な訓練が必要となる ${ }^{5,6) 。 ~}$

OSCE や Post-CC_OSCE では聴診手技の際に, 患者の身体的所見や病態を再現する演技訓練を積ん だ模擬患者に対して, 医療面接と聴診手技を行う。 このとき模擬患者は基本的に健常者であるため, 模 擬患者が再現できる生体音には限界がある。そのた め多くの医学教育機関では, 図 1.1 のように模擬 患者への医療面接を実施した後に, マネキン型聴診 訓練シミュレータに向き直して聴診手技を行うこと が一般的となっている ${ }^{7,8)}$ 。しかし，この方法は医 療面接から聴診手技に移行する際にマネキンに向き 直す動作が必要となり, 訓練効率が低下する可能性 がある。さらに，実際の人体とマネキンには大きな 差異があり，リアリティが久如する。

そこで上野らは, 拡張現実型 (Augmented Reality；AR）技術を用いて模擬患者に対して 様々な症例を再現できる聴診訓練システム E ARS (Educational Augmented Reality auscultation System）を提案した ${ }^{9,10)}$ 。このシステムでは，医 療面接と聴診手技を共に模擬患者に対して実施す ることができ，訓練者は模擬患者に対して模擬聴 診器を用いて通常の診察と同じように聴診を行う。 模擬聴診器のチェストピースが模擬患者に接触す ると聴診位置が取得され，位置に応じて選択され た生体音が再生される。生体音は様々な症例の呼 吸音と心音が用意されている。そのため, 訓練者 は様々な症例の生体音を聴きながら聴診訓練を行 うことができる。しかし従来システムは, 聴診位
置取得に用いるカメラを訓練者の頭上部に設置す るため, 訓練者の診察動作で聴診位置が遮蔽され 動作不良が発生する恐れがあるなどの課題がある。

本研究では, EARSのカメラユニットを模擬聴 診器に搭載した新たな聴診器デバイスについて検 討を行った。また，チエストピースの接触に関わ らず，常に聴診位置を検出する手法を提案した。 設置の簡便さ, 聴診器検出性能について評価を行 い, 従来システムと比較を行った。また, 医学教

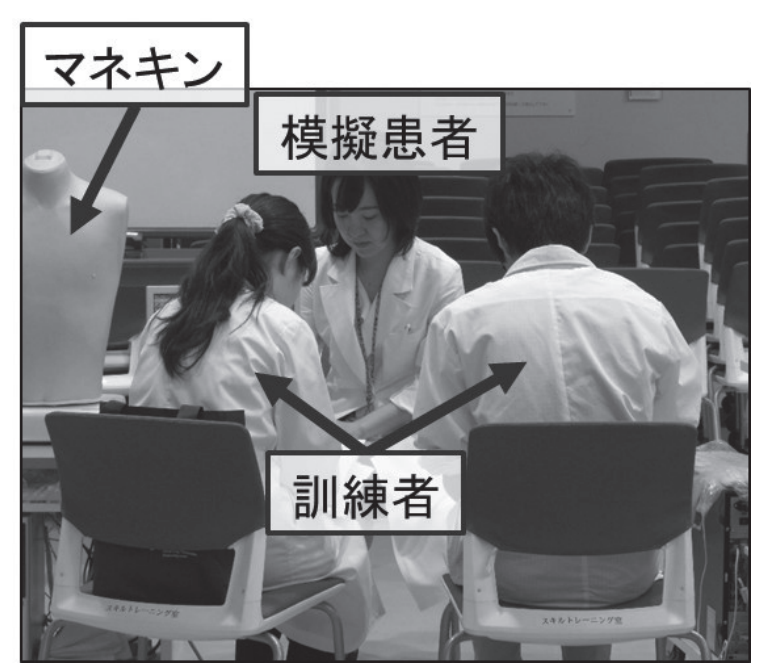

(a) 模擬患者への医療面接

(a) Medical interview to simulated patients

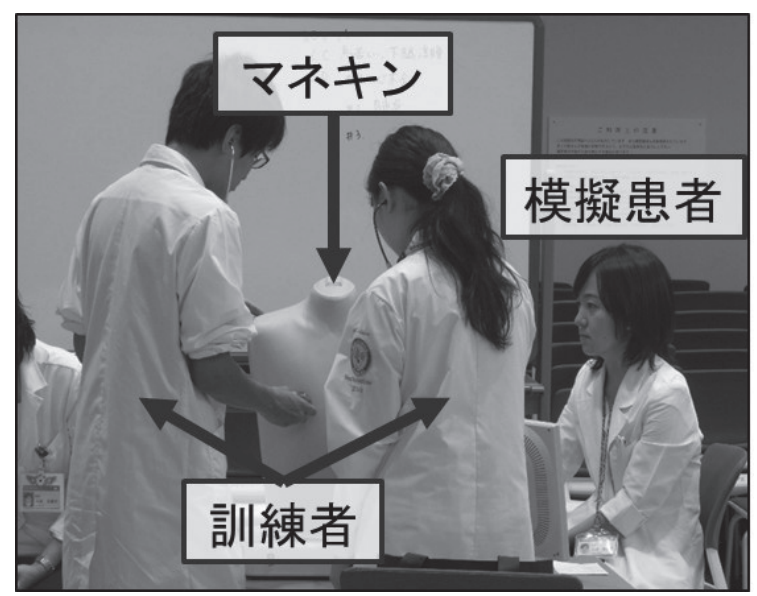

(b) マネキンへの聴診

(b) Auscultation to a mannequin

図 1.1 現在の聴診訓練様子

Fig.1.1 Current auscultatory training 
育試験で使用し，医学部生のアンケートによる評 価を行った。

\section{2. 関連研究}

聴診とは身体が発する心音と肺音の異常から病 気を診断する技術であり，患者の循環状態を取得 するために一般的に用いられる。しかし, 異常生 体音が発生する生体位置は症例ごとに異なるため, 聴診器を通して聴こえてくる聴診音から生体の異 常状態を判別するには，聴診音と聴診位置を関連 付けて覚える必要がある ${ }^{11) 。 ~}$

現在の代表的な聴診訓練として, CD ${ }^{12,13)} や$ e-Learning ${ }^{14)}$ を用いた訓練がある。これらの方法 は, 収録されている様々な症例の生体音を聴き, その知識を習得できる。しかし，聴診位置と聴診 音の関係を把握するには不十分となる。

また，聴診訓練専用スピーカ ${ }^{15)}$ やマネキン型聴 診訓練シミュレータ ${ }^{8)}$ などのデバイスも存在する。 聴診訓練専用スピーカは, 聴診器をスピーカに接 触させることで, 聴診器を通して様々な症例の生 体音を再生することができる。マネキン型聴診訓 練シミュレータは, シミュレータの内部に複数の スピーカが内蔵されており, 聴診位置に応じた生 体音を再生することができる。これらの方法は実 際に聴診器を用いた学習ができ, 希少症例の訓練 や繰り返しの訓練も可能となるため, 診察状況を 自由に設定したシミュレーション訓練に活用され ている。しかし, これらのシミュレータでは患者 に対して聴診器を当てて訓練を行うことはできな い。加えて, マネキン型デバイスはリアリティや 訓練効率が低下寸る可能性が生じ, 非常に高価で あることや広い設置スペースが必要であるため導 入が困難となる場合がある。

上記に加えて, 模擬患者と聴診訓練を行うシス テムも提案されている ${ }^{16)}$ 。このシステムは, デプ スカメラでカラーマーカを貼付した聴診器のチエ ストピースと模擬患者の位置を検出する。また,
デプスカメラで検出した模擬患者の呼吸運動に合 わせて呼吸音を再生できる。これにより模擬患者 に対して直接聴診手技を行うことができる。しか し, デプスカメラは位置検出精度が低いため, チェ ストピースと模擬患者の接触判定の際に接触の誤 判定が生じる問題がある。また，デプスカメラで 検出できる呼吸運動は時間的な遅延を持つため, 呼吸音が再生される夕イミングに違和感が生じる 可能性があることも課題となっている。

\section{EARS}

\section{1 従来システムの構成と課題}

現在の医学教育のシミュレーション訓練におけ るリアリティの欠如などの課題を解決するために, 上野らによって模擬患者を用いた拡張現実型聴診 訓練システム EARSが提案された。EARS は図 3.1 に示すように, 訓練者の用いる模擬聴診器, 赤外 カメラと赤外 LED と呼吸タイミングを指示する呼 吸表示器が一体となったカメラユニット, 反射マー カが設置された模擬患者が着用するべスト, タブ レット PCから構成される。

使用時は, タブレット PC 上でシステムに内蔵 された生体音から学習したい症例を選択し, 訓練 者は模擬聴診器を用いてべストを着用した模擬患 者に対して聴診訓練を実施する。また, 呼吸音再 生時にはカメラユニット内の呼吸表示器で呼吸リ ズムを指示し，模擬患者の胸郭の動きと再生され る呼吸音のリズムを一致させる。

従来の EARSを設置した様子を図 3.2 に示す。 このシステムはカメラユニットを訓練者の頭上部 に設置するため,（i）広い設置スペースが必要，(ii） 模擬患者の姿勢が座位のみに限定，（iii）訓練者の 体などの遮蔽物で赤外光が遮断され動作不良が発 生する恐れがある, といった課題がある。

\section{2 聴診位置の検出}

模擬患者の体型は様々であり, 聴診位置の算出 
のために模擬患者の体型をシステム内の標準座標 系に変換する必要がある。カメラ座標系からシス テム内標準座標系への 2 次元座標変換は式 (3.1)

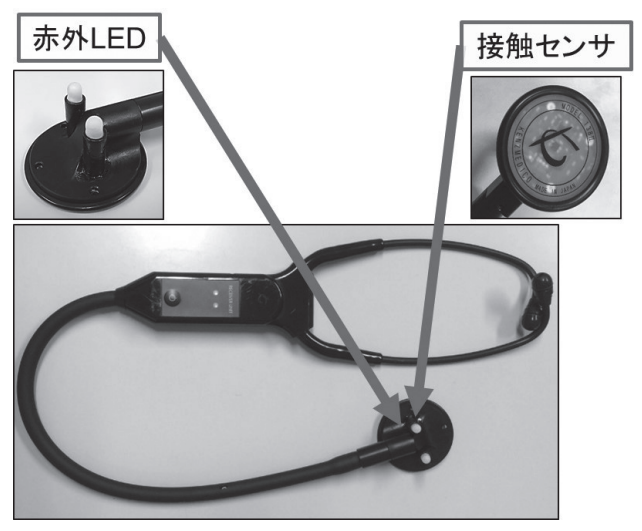

(a) 模擬聴診器

(a) Simulated stethoscope device

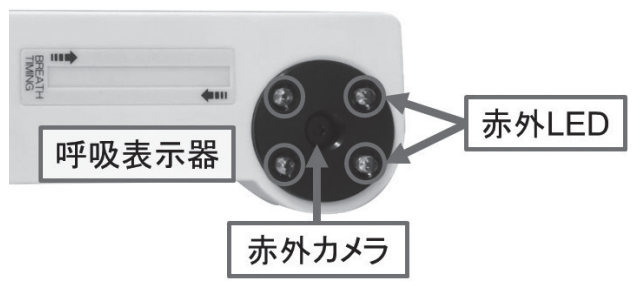

(b) カメラユニット

(b) Camera unit

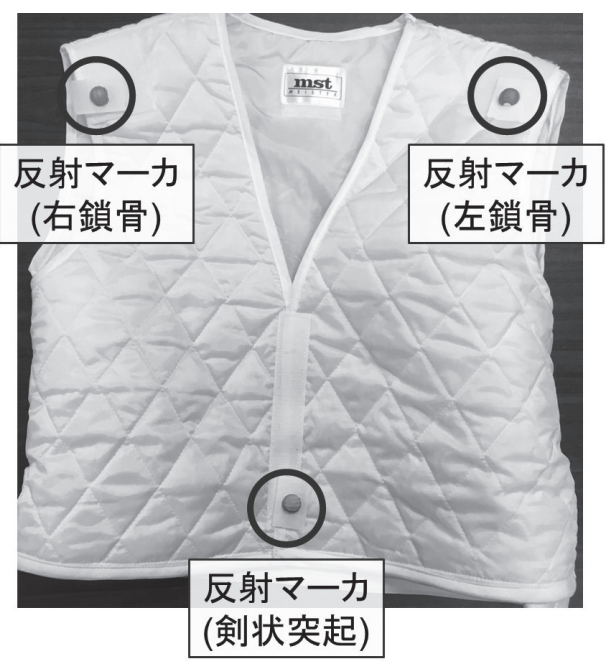

(c) 反射マーカ付きベスト

(c) Vest with reflective marker

図 3.1 システム構成 システム構成

Fig.3.1 System configuration
で行う。この式の $(\mathrm{X}, \mathrm{Y})$ はシステム内座標系, $P_{11}$ $\sim P_{23}$ は変換行列の各要素, $(\mathrm{x}, \mathrm{y})$ はカメラ座標系 である。この式から未知数が 6 個であるとわかる。 すなわち, カメラ座標系からシステム内標準座標 系への変換行列を求めるには対応点が少なくとも 3 点必要といえる。

$$
\left[\begin{array}{l}
X \\
Y
\end{array}\right]=\left[\begin{array}{lll}
P_{11} & P_{12} & P_{13} \\
P_{21} & P_{22} & P_{23}
\end{array}\right]\left[\begin{array}{l}
x \\
y \\
1
\end{array}\right]
$$

本システムではその 3 点を, 図 3.1(c) に示すよ うに反射マーカを貼り付けた模擬患者の左右の鎖 骨と剣状突起としている。システム内標準座標系 での 3 点の位置は既知であり, カメラ座標系に掠 けるそれらの位置検出が必要である。

検出にはカメラユニットの赤外 LED を用いる。 訓練時には，赤外 LED を赤外カメラの撮影と同期 させて点滅させ，LED が ONのときに模擬患者が 着用しているべストに張り付けたマーカで赤外光 を反射する。この反射光から模擬患者のマーカ位 置を取得する。また, 訓練者の用いる模擬聴診器 のチェストピースには接触センサと赤外 LED が内 蔵されており, 聴診器が模擬患者に触れると点灯 する。この光から聴診器の位置を取得する。これ

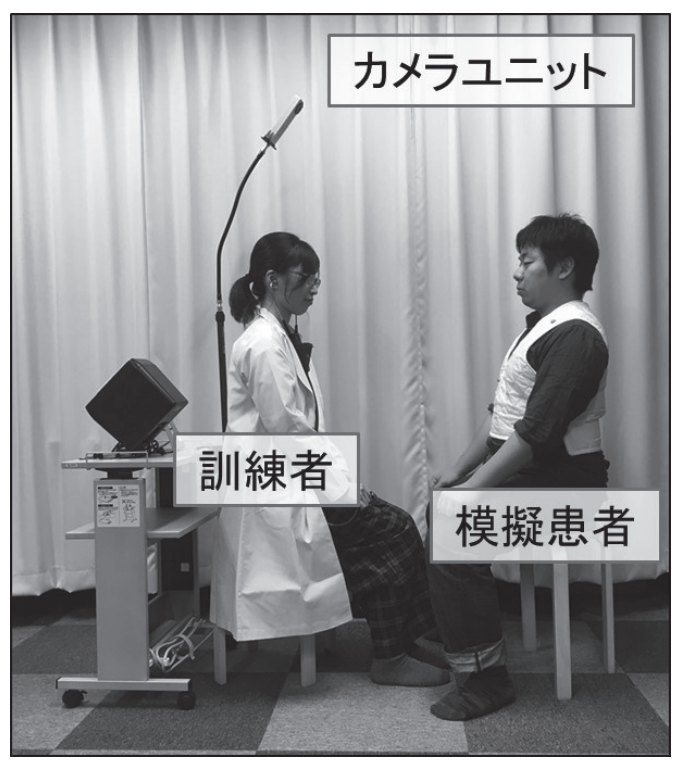

図 3.2 EARS を設置した様子 Fig.3.2 Installation of EARS 
らの赤外光を赤外カメラ画像から取得し, 模擬患 者と聴診器の位置を検出することで, 聴診位置に 応じた生体音の再生が可能となる。

このとき, 赤外カメラ画像からはマーカの反射 光とチェストピースの赤外 LED 光を区別すること ができない。そのため, LEDの点滅が ON の時に 得られる ON 画像と OFF の時に得られる OFF 画 像を用いてマーカと聴診器の位置をそれぞれ算出 する。処理の流れと, マーカ 3 点と聴診器を検出 した場合の取得画像のイメージ図を図 3.3 に示す。

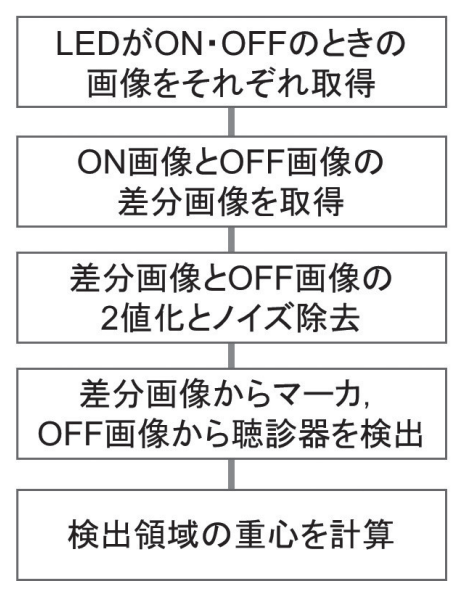

(a) 処理の流れ

(a) Process flow

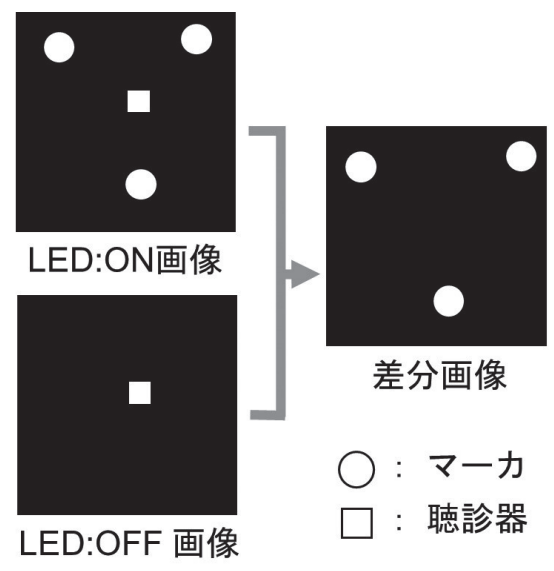

(b) 取得画像のイメージ図

(b) Examples of acquired images

図 3.3 マーカと聴診位置の検出

Fig.3.3 Detection of markers and auscultatory position
OFF 画像から聴診位置, 差分画像からマーカを算 出し, そのマーカ位置から変換行列を求める。仮 にマーカ 3 点が遮蔽物などで検出できなかった場 合は，最後に 3 点が検出できたマーカ位置を用い る。この方法では, 赤外 LED の点滅とカメラの撮 影タイミングの同期が必要となる。

この赤外 LED の点滅はソフトウェア上で制御し ており,「LEDを点灯」「ON 画像を取得」「LED を消灯」「OFF 画像を取得し, 差分画像を算出」 といった 4 つ処理をそれぞれカメラフレーム毎 に行うため, 差分画像を取得してマーカと聴診位 置を検出するまでに 4 フレームを要する。

\section{4. システム改良}

\section{1 システムの拡張}

前節で述べた従来システムの一連の問題は，訓練 者の頭上部に設置したカメラユニットの位置に原因 があると考え, カメラユニットを訓練者が用いる模 擬聴診器に組み込んだカメラ内蔵型聴診器デバイス を開発した。これによりシステムが小型化し, 設置 スペースや赤外光を遮る遮蔽物の減少が図られる。 また，カメラが一点に固定されないため，訓練者や 模擬患者への姿勢の制限が減少する。

\section{2 聴診器デバイス}

製作したカメラ内蔵型聴診器デバイスを図 4.1 に示す。従来のカメラユニットの機能を全て聴診 器デバイスに導入するため, 赤外カメラ, 赤外 LED, 呼吸表示器を搭載した。呼吸表示器は有機 $\mathrm{EL}$ パネルに表示したバーを上下させることによ り, 模擬患者の呼気・吸気の夕イミングを指示する。 模擬患者がこの表示に合わせて呼吸を行うことで, 再生される呼吸音と模擬患者の呼吸リズムを同期 させる。また，従来は電池により駆動しており生 体音を無線通信（Bluetooth A2DP）により再生し ていたが, 新たな聴診器デバイスは有線ケーブル 給電により駆動しており生体音も有線で通信する。 
今回搭載したカメラはアサヒ電子研究所の CM418$2 \mathrm{~A} （$ 解像度 $640 \times 480 ）$ であり，フレームレートは 30fpsである。レンズは，様々な模擬患者と訓練者 の姿勢に対応するため広い画角が必要となる。画 角 $180^{\circ}$ の魚眼レンズでは蛍光灯などのノイズを 検出しやすくなるため, 今回は画角 $159^{\circ}$ のレン ズを採用し，可視光 $(780 \mathrm{~mm}$ 以下の波長）を遮る 赤外フィルタを装着した。また，ゴム管の長さが 短いと聴診手技によってカメラが上向きに傾き,

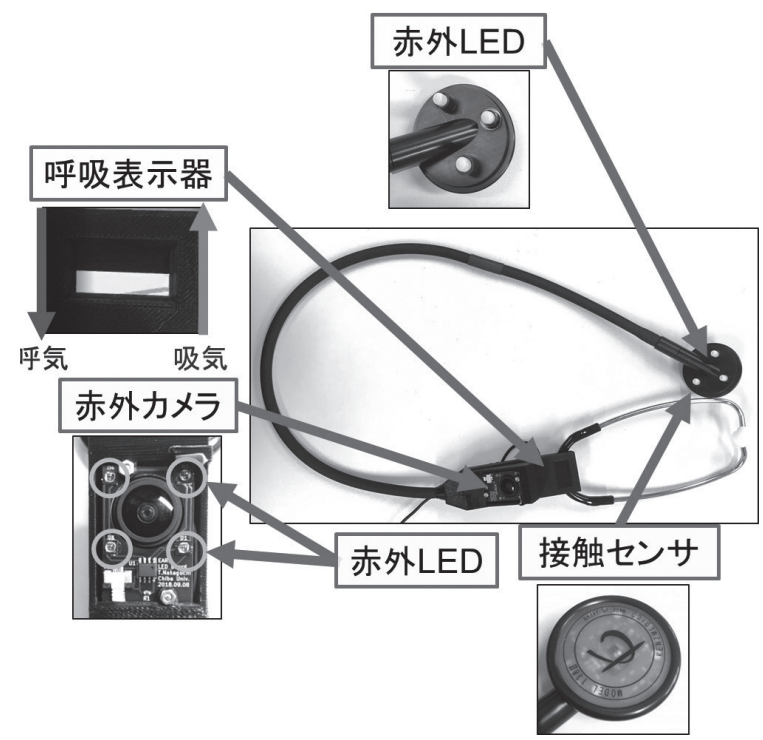

図 4.1 カメラ内蔵型聴診器デバイス

Fig.4.1 Camera built-in stethoscope device

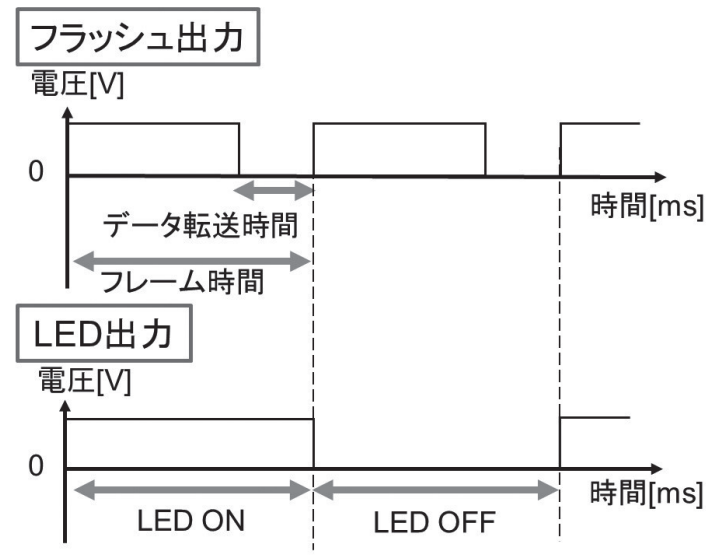

図 4.2 カメラのフッラシュ出カと LED 点滅 Fig.4.2 Camera flash output and flashing LED
画角内から模擬患者が外れる恐れがあった。その ためゴム管の長さは，手技によってカメラの傾き が生じず，模擬患者を常にカメラ画像の中心で撮 影できる $70 \mathrm{~cm}$ とした。通信ケーブルを含めた聴 診器デバイスの総重量は $238 \mathrm{~g}$ である。

聴診器デバイスは, 従来システムと同様にカメ ラユニットの赤外 LED 点滅と撮影タイミングの同 期が必要となる。従来はソフトウェアで LED 点滅 を制御していたが，今回はハードウェア制御によ りカメラのフラッシュ制御と同期して点滅をさせ る。カメラのフラッシュ出力と LED 点滅の制御方

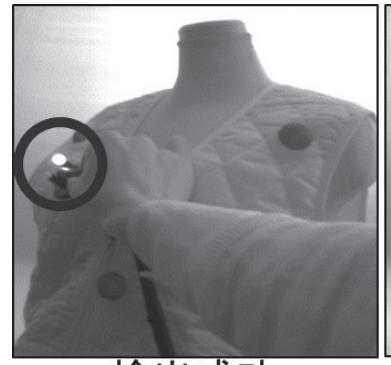

検出成功

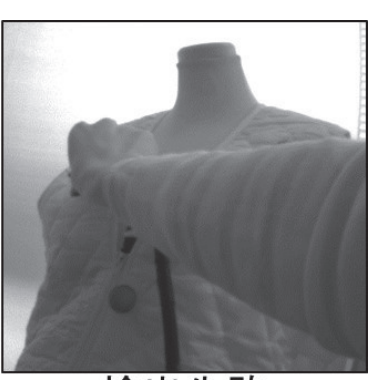

検出失敗
図 4.3 検出エラー例

Fig.4.3 Example of detection error

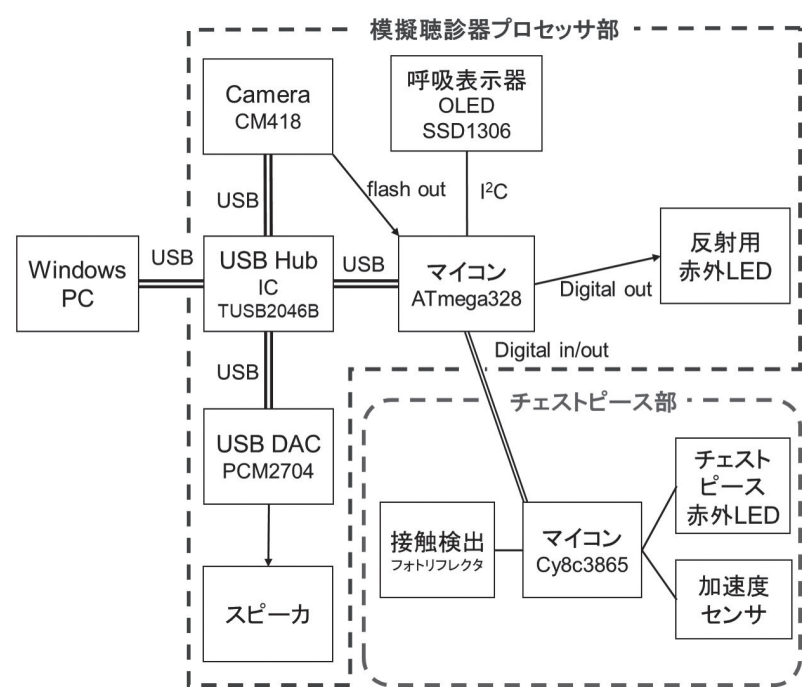

図 4.4 回路構成図

Fig.4.4 Circuit configuration diagram 
法を図 4.2 に示す。フラッシュ出力はフレームが 切り替わるタイミングで電圧が上がり，一定時間 が経過しデー夕転送時間となると電圧が低下する。 カメラ動作中はこの波形を繰り返す。すなわち, 電圧が立ち上がるタイミングでLEDの ON/OFF を繰り返すように回路を設計すると，フレームご とにLED が点滅した画像を交互に取得できる。な お，今回は赤外 LED を用いたため点滅光は可視で きず，眩しいと感じることはない。

提案システムを訓練に使用すると, 図 4.3 に示 すように，カメラと手の位置関係によってチェス トピースの赤外 LED の遮蔽が生じることがある。 そのため, センサの接触に関わらず聴診位置を常 時検出し, 仮に接触時に赤外 LED が遮蔽されても, その直前まで検出できていたチェストピース位置 を参照して生体音再生を行う。従来はチェストピー スの赤外 LED は，接触センサが生体に触れると点 灯していたが, 提案システムは接触の有無に関わ らず，カメラユニットの赤外 LED の点滅周期と反 転させて常に点滅をさせた。ON/OFF のタイミン グが反転するため, マーカの反射とチェストピー スの点灯は同時には発生しない。このとき, 接触 センサが生体に接触するとタブレット PCに信号 を送信し，検出した聴診位置を用いて，その位置 に応じた生体音を再生する。

前述した制御を行うために聴診器デバイスの回路 を作製した。ブロック図を図 4.4 に示す。USBで カメラ, イヤーピース部のスピーカ, マイクロコン ピュータ（マイコン）と通信を行う。マイコンは呼 吸バーの表示や, カメラから送信されたフラッシュ 出力と同期して反射用赤外 LED の点滅を制御する。 同様にチェストピース部のマイコンも, チェスト ピース部の LED を反射用赤外 LED と反転させて 点滅させる。また, このときチェストピース部に設 置されている 3 つの LEDのうち, いかなる持ち方 でも遮蔽が生じにくい上部の LED のみを点滅させ る。そのため, 加速度センサで常にチェストピース の傾きを判断し，上部の LED がどれかを識別する。
フォトリフレクタによる接触検出もマイコンで制御 し，接触を検知すると PCに信号を送信する。

提案システムを設置した様子を図 4.5 に示す。 カメラユニットを聴診器デバイスに内蔵したこと で，訓練者の頭上部にカメラユニットを設置する 煩雑さが解消され, 従来システムと比べて設置ス ペースが減少した。

\section{3 聴診位置検出手法}

4. 2 節に示した聴診器デバイスでは, チェスト ピースの赤外 LED が常に点滅するため, 新たな マーカと聴診器の判別方法が必要となる。処理の 流れと, マーカ 3 点と聴診器を検出した場合の取 得画像の例を図 4.6 に示す。提案手法では, 2 つ の差分画像を算出して差分画像 1 からマーカ, 差 分画像 2 から聴診器を検出する。差分をとること で, ON 画像・OFF 画像に共通して写る, 環境に 存在する赤外光の日光や蛍光灯などの外乱は除去 できる。EARS 動作中はこの処理を常に行い, 新 たにカメラ画像を取得する度に, マーカと聴診器 の位置を検出する。このとき, 接触センサが生体 に触れると最新の検出結果を用いて生体音を再生

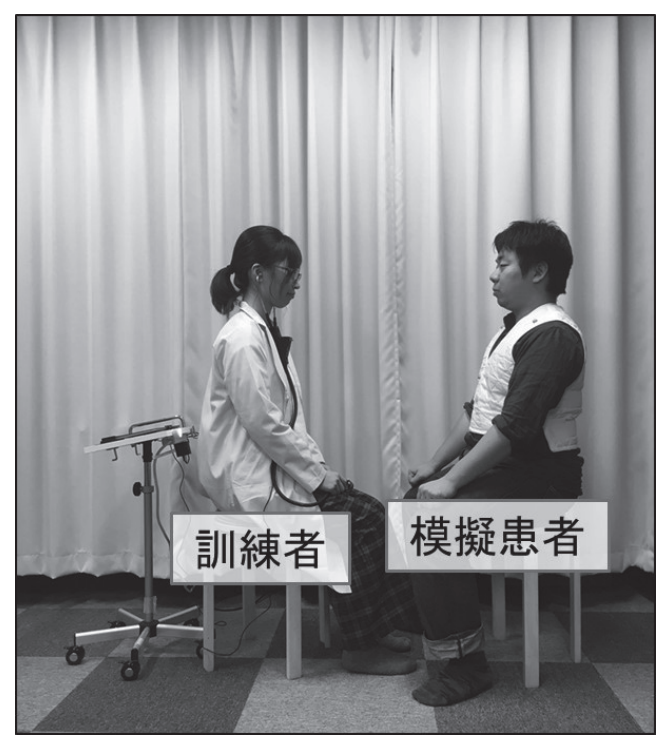

図 4.5 提案システムを設置した様子 Fig.4.5 Installation of proposed system 
する。また，接触時にチェストピースの赤外 LED が隠れていた場合は, 最後に検出したチェストピー ス位置を参照して生体音の再生を行う。

本手法では 1 つ目の差分画像の算出には2 フレー ムが必要だが，以降は ON 画像か OFF 画像のど ちらかを更新してその都度差分画像を算出するた

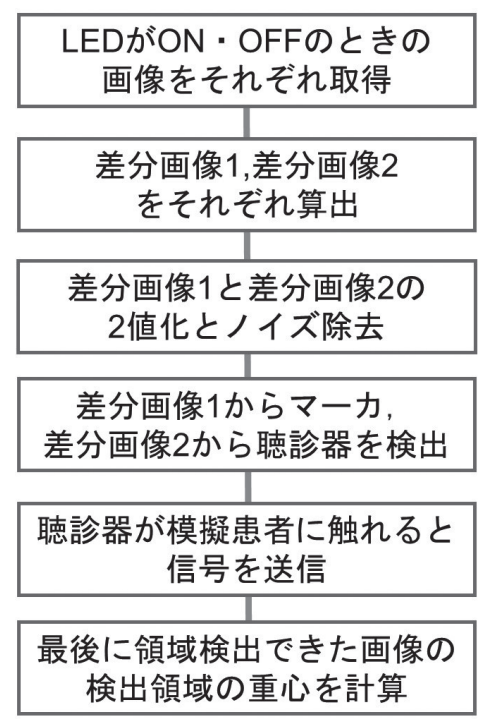

(a) 処理の流れ

(a) Process flow

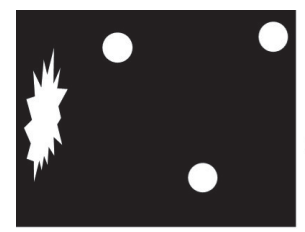

LED:ON画像

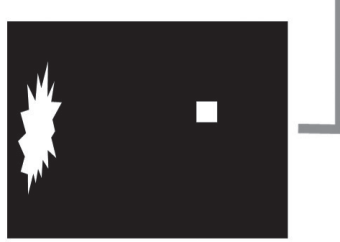

LED:OFF画像

○: マーカ

(b) 取得画像のイメージ図

(b) Examples of acquired images

図 4.6 新たなマーカと聴診位置の検出

Fig.4.6 New detection method of marker and auscultation position
め, 毎フレームでの差分画像の算出が可能となる。 すなわち, カメラのフレームレートが最大 $30 \mathrm{fps}$ であるため，模擬患者と聴診器の位置はそれぞれ $15 \mathrm{fps}$ で検出可能となる。聴診手技により聴診器が 大きく動くことはなく, 位置検出に時間的な遅延 を感じることはない。また, 差分像算出までの計 算時間もカメラの 1 フレーム当たりの処理時間で ある $33 \mathrm{~ms}$ を下回るため, 安定して差分像を算出 することが可能となる。これにより, 従来と比べ て検出結果が得られるまでのフレーム数が減少し, 効率的な検出が可能となった。

また，この処理では取得した画像が ON 画像か OFF 画像かの判断が必要となる。そのため, 図 4.7 に示すような反射板をカメラ撮影画像の左上部に 写るように設置した。この反射板はLED が ONの 時にだけ撮影されるため, 撮影画像に反射板が写っ ていることでLEDの点滅を判断する。

\section{5. 実験・評価}

\section{1 評価実験}

\section{1.1 実験概要}

提案システムと従来システムを用いて, 聴診器 のチェストピースの検出性能を比較する実験を

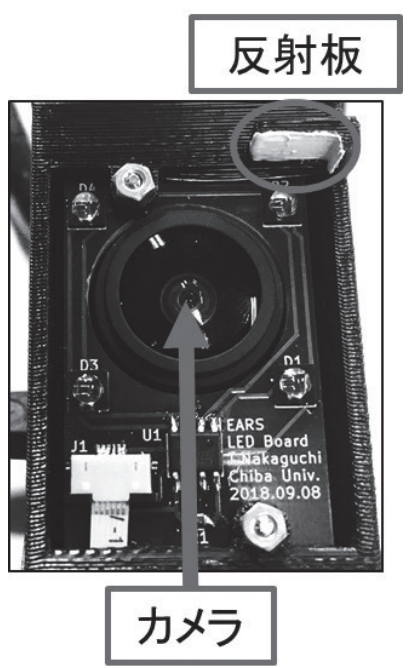

図 4.7 反射板

Fig.4.7 Reflective part 
行った。着座した被験者が, ベストを着用し椅子 に座ったマネキンに対して聴診を行い，チェスト ピースの位置を正確に検出できなかった回数を計 測した。図5.1(a)に示す呼吸音診察に用いる $9 つ$ の聴診部位に対して 1 回ずつ, 1 セットの聴診を 行った ${ }^{17)}$ 。マネキンとの位置関係は，図 5.1(b)に 示す正面・左・右からの 3 パターンで実施した。 聴診開始時の左右の角度はともに $45^{\circ}$ と設定した が，聴診手技中に被験者の体が動くため角度は固 定されない。一般的に心音は呼吸音より聴診領域 が狭いため, 呼吸音の聴診部位を用いた ${ }^{11)}$ 。被験 者は $22 \sim 27$ 歳の男女計 10 名であり, 1 人 2 回行っ た。なお，チェストピースを持つ手は右手で統一 した。

全ての測定結果を集計し, 向きごとに 1 セット 当たりのチェストピースの検出エラー回数を算出 し，評価を行った。

\section{1.2 実験結果}

平均検出エラー回数の算出結果を図 5.2 に示す。 結果から, 従来システムと比べて, 各測定での提 案システムの検出エラー回数の減少が確認できた。 また，5\% 水準で $\mathrm{t}$ 検定を行い，左右共に従来シス テムとの有意差が確認された。これは, カメラ位 置の変更により, 訓練者の体による遮蔽や環境に

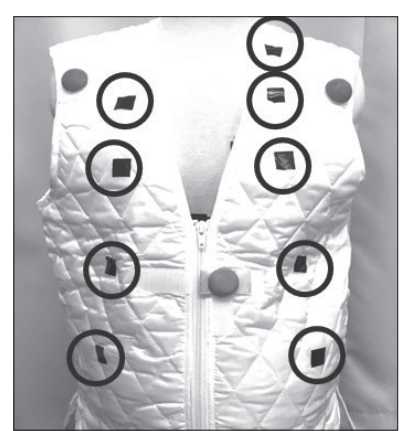

(a) 聴診位置

(a) Auscultatory position

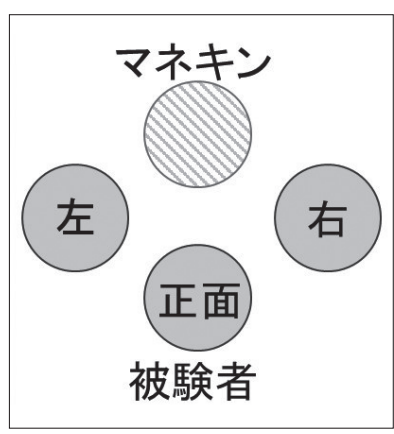

(b) マネキンとの位置関係

(b) Position relationship
図 5.1 実験環境

Fig.5.1 Experiment environment
存在する蛍光灯などの外乱の検出が減少したこと が考えられる。

しかし実験では, 左右共に検出エラーが 1 例ず つ検出された。これは, 点滅しているカメラユニッ トの赤外 LED の反射が，チェストピースを持つ被 験者の右腕で生じたことでマーカ位置の誤検出が 発生し, マネキンの位置を正確に取得出来ず，聴 診位置の識別が失敗したためである。この検出エ ラーは, 腕での反射が発生しないようにカメラの 露光量を調整することで解消できると考えられる。 よって以上の結果から, 提案システムにより EARS の聴診器検出性能の向上を確認した。

提案システムは循環器内科・呼吸器内科・医学 教育分野各医師の意見を統合して, 聴診位置に応 じた生体音の再生に用いる音量マップの設計分解 能を約 $20 \mathrm{~mm}$ にしており, 位置検出の要求性能も $20 \mathrm{~mm}$ 以下となる。聴診器位置はチェストピースの LED の発光位置を使用するため, 位置検出精度は 訓練者と模擬患者の対面角度に依存して変化する。 訓練者と模擬患者が正対する場合の位置検出精度 が最も高く，基本的に検出位置がずれることはな い。模擬患者の正面から $\theta$ 度, 訓練者の位置が左 右いずれかに移動すると，位置検出は $h \tan \theta(\mathrm{mm})$ だけずれて誤差となる。ここでんはチェストピー スに取り付けたLED の高さであり, 現在の設計で は持った手による干渉を防ぐため $12 \mathrm{~mm}$ としてい る。すなわち, 提案システムでは $\theta$ が約 $60^{\circ}$ 未満

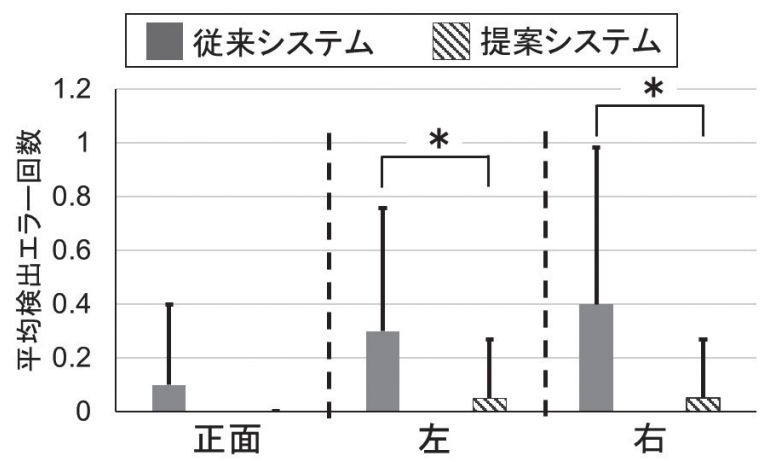

図 5.2 実験結果

Fig.5.2 Experimental result 
のとき, 要求性能を満たすことができる。

評価実験では，左右での聴診開始時の対面角度 $\theta$ を $45^{\circ}$ と設定したため, 常に位置検出の要求性能 を満たすことができた。

\section{2 医学教育への導入}

千葉大学医学部の常置委員会である臨床カリ キュラム部会での承認を得て，提案システムを医 学部附属病院で実施された医学部 6 年生を対象と する試験に導入した。

本試験で EARS は診察室に各 1 台ずつ配置され, 受験生による模擬患者の胸部聴診手技に用いられ た。受験生は計 131 名である。試験終了時に受験 生全員に対して, 聴診器デバイスを用いた EARS システムの使いやすさの評価を目的としたアン ケートを実施した。回収率は100\%である。質問 は全 7 問であり，Q1〜Q6 は 1〜 5（1：いいえ, 5：はい）の 5 段階の Likertスケールであり，Q7 は EARSに関する意見や要望などの自由記述回答 とした。

表 5.1 アンケート内容

Tab.5.1 Questionnaire contents

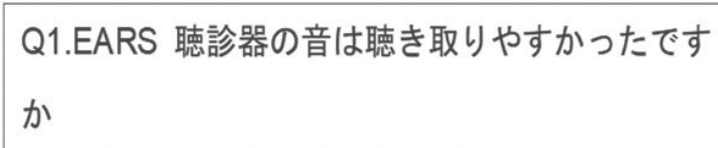

Q6.EARS 聴診器の重さは通常より重いですが、 許容できますか

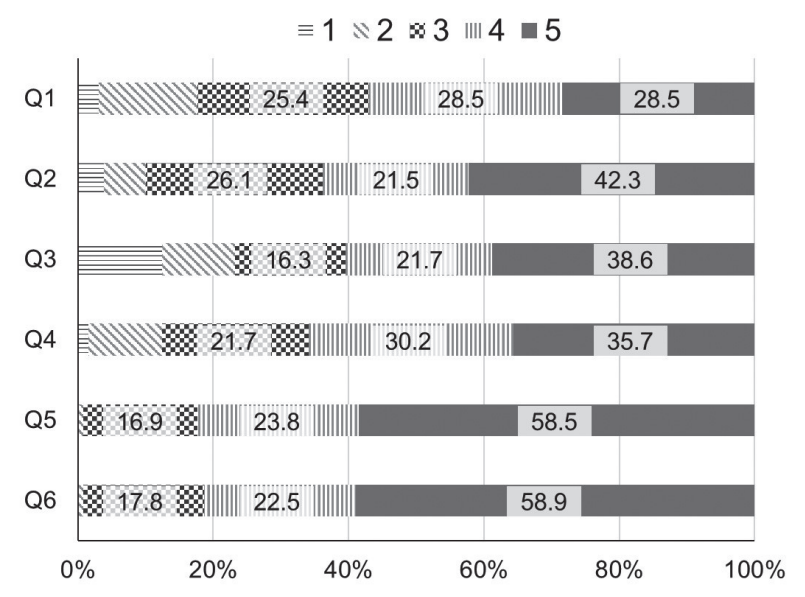

図 5.3 アンケート回答結果

Fig.5.3 Questionnaire response result

$\mathrm{Q} 1 \sim \mathrm{Q} 6$ の質問内容を表 5.1, 各問での回答結 果を図 5.3 に示す。すべての問で好評を示す $4 \cdot 5$ が占める割合が $50 \%$ 以上であり，提案システムの 有用性が確認できた。しかし，Q1〜Q4 に関して は Q5・Q6 と比べて 1・2 が占める割合が大きく, 更なる評価の向上が望ましい。Q1, Q2 は再生さ れる生体音をより現実に近付けるために, 音が鳴 る範囲や音量に関して再度設定を行う必要がある。 Q3 はケーブルを用いない, 無線でのカメラ画像伝 送の可能性を検討する必要がある。Q4 は繰り返し 使用し慣れるとともに，チェストピースの形状の 改良を検討する必要がある。

また，Q7で「模擬患者の胸郭の動きと再生され る呼吸音にずれがあり分かりにくい」という回答 が多数見られた。提案システムでは呼吸表示器で 呼吸リズムを指示しており，表示バーが上下する 時間と音源の再生時間を同期させ，バーが上がる ときは吸気，下がるときは呼気の生体音を再生し ている。すなわち，模擬患者が表示バーに従わず 呼吸した場合，実際の胸郭の動きと再生される生 体音にずれが生じるため, 深呼吸や息止めには対 応できないという問題点がある。この問題は, 呼 吸表示器を用いた現システムでは解消できない。 そのため, 模擬患者の呼吸リズムを自動的に検出 
し，検出された呼吸リズムに合わせて呼吸音を再 生する必要がある。

検出方法として, 模擬患者の胸郭に圧力センサ を内蔵したバンドを巻き付ける呼吸検出法が, 先 行研究にて実施されており，EARSへの導入の検 討を行う ${ }^{18)}$ 。また, ベッドに内蔵されたセンサに よって，寝ている人間の呼吸リズムを検出するシ

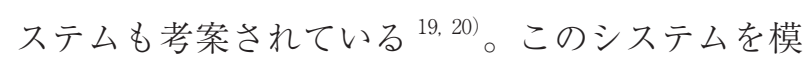
擬患者の座る椅子に応用可能かの検討も行う予定 である。

\section{6. 結論}

本研究では, 拡張現実感技術を用いた聴診訓練 システム EARSのデバイス改良を行い, 従来シス テムでは訓練者の頭上部にあったカメラユニット を聴診器に組み込んだカメラ内蔵型聴診器デバイ スを開発した。これによりシステムの小型化を実 現し, マーカと聴診器位置の検出結果を得るため に必要なフレーム数が減少した。さらに, チェス トピースの接触に関わらない, 聴診器位置の常時 検出が可能となった。

評価実験により聴診器の検出性能向上を確認し, 医学教育試験にて提案システムを使用した。また, 試験の受験者アンケートからシステムの有用性を 評価した。

今後は,アンケートを基にしたシステムの改善 を行う。具体的には，再生される生体音をより現 実に近付けるための音源の編集や, 模擬患者の胸 郭の動きと再生される呼吸音を同期させる方法を 検討する。また，仰臥位などの様々な体位の模擬 患者を想定した評価実験の実施を検討している。

\section{参考文献}

1）佐藤亜紀，永松有紀，松村智大：看護教育における 臨地実習前の成人看護学 (急性期) 客観的臨床能力 試験 (OSCE) の実際と課題。産業医科大学雑誌, 40(3):267-274, 2018.

2）舛形尚, 岡田宏基, 余島侑子, 他: 共用試験 OSCE 後 の臨床実習に打ける模擬患者による医療面接実習の 意義と問題点.医学教育, 40(3):175-179, 2009.

3）共用試験実施評価機構と共用試験。 https:// w w w. mhlw.go.jp/file/05-Shingikai-10801000-IseikyokuSoumuka/0000181638.pdf, (Referred Dec.11, 2018.)

4）高階經和: 誕生から 200 年, 聴診器の歩みを見つめ る時だ。日内会誌, 105:861-865, 2016.

5）村田朗: 医学教育に抒ける肺聴診と OSCE. 日本胸部 臨床, 63:637-643, 2004.

6) John Butter, William C. McGaghie, Elaine R. Cohen, et al..: Simulation-based Mastery Learning Improves Cardiac Auscultation Skills in Medical Students. J Gen Intern Med, 25:780-785, 2010.

7）別府正志, 奈良信雄, 鈴木利哉, 他: シミュレータを 用いた心臟病診察のスキル訓練セミナーとその評価. 医学教育, 40(6):419-424, 2009.

8）株式会社京都科学 心臟病診察シミュレータ”イチ ローII A” . https://www.kyotokagaku.com/jp/, (Referred Nov.22, 2018.)

9) Toshiya Nakaguchi, Tatsuya Ueno, Torakazu Muratake, et al..: Development of VR-Based Auscultation Training System Using Simulated Patient. Journal of Medical Imaging and Health Informatics, 3(1):89-93, 2013.

10）上野達也, 中口俊哉, 村竹虎和, 他: 模擬患者を用い た聴診訓練シミュレータの構築. VR 医学会学術大会 抄録集 , 12(1):22-22, 2012.

11）聴診器をベッドサイドで使いこなそう.http://www. kenzmedico.co.jp/others/bedside/bedside.html, (Referred Nov.22, 2018.)

12）川城丈夫：CDによる聴診トレーニング呼吸音編. 南江堂, 2011

13）沢山俊民：CDによる聴診トレーニング心音編． 南江堂, 1994

14）公益社団法人臨床心臟病教育研究会ジェックス e-Learning Auscultation. https://www.jeccs.org/ contents/eLearning/choshin/, (Referred Nov.22, 2018.)

15）株式会社テレメディカ 聴くゾウ . https://3sportal. telemedica.co.jp/home/, (Referred Nov.22, 2018.) 
16）村田嘉利, 吉田和広, 三浦奈都子, 他：KINECT\& Azure を利用した聴診演習システムの開発。マルチ メディア，分散協調とモバイルシンポジウム 2016 論文集, 308-313, 2016

17）岡三喜男: 読む肺音視る肺音 病態がわかる肺聴診学. 金原出版, 2014

18）岩崎翔子, 中口俊哉, 村竹虎和, 他: 拡張現実型聴診 訓練システムの呼吸リズム追従再生の検討. 第 17 回 日本 VR 医学会学術大会抄録集, OP1-3, 2017.

19) Sooji Park, Hangsik Shin: Feasibility Study for Unconstrained Respiration Monitoring Based on Multi-Way Approach Using an Acceleration and Force Sensing Module. IEEE Sensor Journal, 17(11):3482-3489, 2017

20）株式会社パラマウントベッド 眠り SCAN. https:// www.paramount.co.jp/learn/reductionworkburden/ nemuriscan, (Referred Nov.22, 2018.) 